VISION: Journal of Indian Taxation Volume 4, Issue 1, January-June 2017, pp. 19-39 doi: 10.17492/vision.v4i01.9991

\title{
International Tax Avoidance and Evasion with Special Reference to India
}

\author{
M M Sury*
}

\begin{abstract}
International tax avoidance and evasion is a serious problem in developing countries where the tax systems are still evolving. While it is true that international business operations are exposed to the risk of being subject to double taxation, such activities also provide various opportunities for tax avoidance and evasion. This paper analyses the various methods adopted for international tax evasion and avoidance such as tax treaties, tax havens, and transfer pricing. It also examines the general causes of this evasion along with the detrimental impact that it has on the economy. In addition, it discusses the various estimates of tax evasion in India from time to time. While examining the history of taxation law amendments in India, it is seen that it is essentially a history of plugging loopholes, as and when discovered, to prevent leakages of revenue rather than making structural changes in the taxation system to strike at the root cause of the problem. India needs tougher laws and stricter enforcement of existing provisions to deal with the root causes of international tax evasion and avoidance.
\end{abstract}

Keywords: International tax evasion; Tax avoidance; Tax havens; Transfer pricing; Tax treaty shopping.

\subsection{Introduction}

Tax evasion exists in all countries, though in varying degrees. It is a serious problem in developing countries which are in the process of evolving their tax systems. Tax evasion is an illegal attempt to reduce the tax payable by deliberately underreporting or not reporting taxable incomes or concealing one's true state of affairs from tax authorities. Tax evasion is a criminal offence and if detected is punishable by financial penalties or even by imprisonment or both.

*Formerly Economic Advisor - Delhi State Finance Commission, Formerly Reader, University of Delhi, Delhi, India. (Email id: editorial@journalpressindia.com) 
Tax avoidance means preventing or reducing one's tax liability through manipulations within the framework of existing tax legislation. Tax avoidance, as against tax evasion, is legally permissible and hence a legitimate aim of taxpayers. Tax avoidance is resorted to through such devices as formation of holding companies to claim artificial deductions, constitution of trusts and family partnerships, transfer of income earning assets to one's wife and children for fractioning income for tax purposes, investing in provident funds and life insurance policies, and manipulation of capital gains. Since tax avoidance has a colour of legality about it, clever taxpayers do their best to avoid or keep down tax payments. This may force the government to raise tax rates, making the less clever assessees bear a disproportionate tax burden. Tax laws in many countries incorporate anti-tax avoidance provisions under which certain incomes are included in an assessee's total income, though such incomes legally belong to other persons. For example, in India, sections 60 to 65 of the Income Tax Act, 1961, deal with instances where an assessee may attempt to reduce his tax liability either by transferring his assets in favour of his family members or by arranging his sources of income in such a manner that tax incidence falls on others, whereas benefit of income, directly or indirectly, is derived by the assessee himself. Thus, income arising to the spouse, minor child, son's wife, son's minor child and certain other persons are clubbed with the assessee's income in certain circumstances. In this regard, the Indian income tax law deviates from the general principle that a person can be assessed in respect of his own income.

\subsection{International Tax Avoidance and Evasion}

While it is true that international business operations are exposed to the risk of being subject to double taxation, it cannot be gainsaid that such activities provide opportunities for tax avoidance/evasion. Following are the devices generally applied for the purpose.

\subsection{Transfer pricing}

It refers to the price attached to transactions between the divisions (e.g. branches or subsidiaries) of a company. Transfer pricing is usually considered in a global context, particularly in relation to cross-frontier transactions within a multinational company. Determination of transfer price has significance in relation to such matters as taxation, exchange restrictions, and currency fluctuations. The incentive for transfer price manipulations is provided by varying rates of taxation in countries where a multinational company operates. Thus, where goods are being transferred from a company in a low tax country to a subsidiary company in a high tax country, there is a clear tax incentive if a high 
transfer price is ensured to maximise profit within the low tax country. Similarly, sales of a multinational group may be routed through a specially formed tax haven distribution company. The tax haven company purchases goods from affiliated companies at the lowest possible prices and sells to independent purchasers at the full market price, ensuring that most or all of the profit from the transaction is earned in the tax haven. Due to the inherent difficulties in determining a fair or market price for inter-company transactions, a multinational company has always the option to fix artificial transfer prices.

\subsection{Tax havens}

The term tax haven has been widely used since the 1950s. However, there is no precise definition of the term. The expression is used to describe any country or locality which levies very low taxes, or none at all, on foreigners. Tax havens can be broadly classified into three categories based on the degree of tax concessions.

(i) Where there is no tax at all, e.g. Bahamas, Bermuda, and Cayman Islands.

(ii) Where only a low rate of tax is imposed, e.g. British Virgin Islands, Hong Kong, Isle of Man.

(iii) Where the tax system favours particular activities or entities, e.g. Luxembourg, Panama, and Switzerland.

Tax havens are used in a number of ways to avoid/evade high taxes of non-tax haven countries. The commonest device is to use a tax haven only as a conduit for transactions the real economic impact of which is located elsewhere. Thus, international transactions between two high tax rate countries may be channelled through a tax haven company so that any resulting profit is realised in the tax haven with a consequent minimisation of tax.

The Organization for Economic Co-operation and Development (OECD) initially defined tax havens as being characterised by no or very low taxes, lack of effective exchange of information, and lack of transparency about substantial activities. It listed 35 countries/jurisdictions as tax havens in the year 2000.

\subsubsection{Offshore Financial Centres}

Some of the old tax havens have adopted the more benign designation of offshore financial centre (OFC) and tend to describe themselves as financial centres specialising in non-residential financial transactions. However, with their array of secrecy provisions that lack regulation, zero or near zero taxation imposed by them, and lack of adequate capital controls, they are logical extensions of the traditional tax havens. The International Monetary Fund (IMF) has defined OFCs as centres where the bulk of 
financial sector transactions on both sides of the balance sheet are with individuals or companies that are not residents, where the transactions are initiated elsewhere, and where the majority of the institutions involved are controlled by non-residents. Thus, many OFCs have the following characteristics:

(i) Jurisdictions that have financial institutions engaged primarily in business with nonresidents.

(ii) Financial systems with external assets and liabilities out of proportion to domestic financial intermediation.

(iii) Centres which provide some or all of the following opportunities: (a) low or zero taxation, (b) moderate or light financial regulation, and (c) banking secrecy and anonymity.

Various studies on tax havens have shown that tax havens are typically small countries/jurisdictions, with low or nil taxation for foreigners who decide to come and settle there. They usually also offer strong confidentiality or secrecy regarding wealth and accounts, making them very attractive locations for safe keeping of unaccounted wealth. They also offer a very liberal regulatory environment and allow opaque existence, where an entity can easily be set up without indulging in any meaningful commercial activity and yet claim to be a genuine business unit, merely by getting itself incorporated or registered in that jurisdiction. This makes them highly desirable locations for multinational entities wishing to reduce their global tax liabilities. These multinational entities — consisting of a network of several corporate and non-corporate bodies - may set up conduit companies in tax havens and artificially transfer their income to such conduit companies in view of the low tax regime there. There is increasing global awareness and concern about the role of tax havens and their facilitation of certain abusive and undesirable arrangements that result in significant fiscal challenges to other countries and also pose a threat in terms of potential financing of terrorism and other activities that threaten peace and security.

The role of tax havens has gradually come under scrutiny globally. With nearzero tax regimes, banking secrecy, and weak financial regulations, these tax havens facilitate hiding of money accumulated through tax evasion and other illegal means in addition to creating risks of terrorist financing and money laundering. At the G-7 summit in Lyons in 1996, a call was given to the OECD to prepare a report to address these issues with a view to establishing a multilateral approach under which countries could operate individually and collectively to limit the extent of these practices. The OECD came up with a report in 1998 and called for action against tax havens. The report envisaged blacklisting of and internationally coordinated sanctions against havens that persisted in luring other states' tax bases. 


\subsection{Tax treaty shopping}

It is a situation where a person resident in a third country seeks to obtain benefits of a double tax treaty between two other countries. A double tax treaty confers substantial benefits on the residents of treaty countries. Let us suppose that a resident in country A, wants to invest in country B. Assuming that there is no double tax treaty between country A and country $\mathrm{B}$, any income received by this person will be subject to full rates of taxation in country B. In such a situation, the person may find it advantageous to channel his investment to country B through a company in country $\mathrm{C}$ because country $\mathrm{C}$ has double tax treaties with countries $\mathrm{A}$ and $\mathrm{B}$. For example, Mauritius is a popular treaty shopping haven for many foreign companies for channelling investments into India because of favourable tax treaty provisions.

\subsection{Participatory Notes (PNs)}

A participatory note (PN) is a derivative instrument issued in foreign jurisdictions, by a foreign institutional investor (FII)/or one of its associates, against underlying Indian securities.

PNs are popular among foreign investors since they allow these investors to earn returns on investment in the Indian market without undergoing the significant cost and time implications of directly investing in India. These instruments are traded overseas outside the direct purview of Securities and Exchange Board of India (SEBI) surveillance thereby raising many apprehensions about the beneficial ownership and the nature of funds invested in these instruments. Concerns have been raised that some of the money coming into the market via PNs could be the unaccounted wealth camouflaged under the guise of FII investment. SEBI has been taking measures to ensure that PNs are not used as conduits for black money or terrorist funding.

\subsection{Investment through complex derivative instruments}

With increasing sophistication of derivative instruments ${ }^{4}$, new opportunities for investing and making profits without being subjected to taxes and regulations are also opening up. Such innovative means can also be misused by unscrupulous parties to generate unaccounted income. Some such instruments like participatory notes may not be adequately covered by regulatory mechanisms and their oversight and hence have potential for misuse.

\subsection{Evasion of specific taxes}

Evasion of specific taxes such as income tax, customs duties, VAT etc. takes place through different types of malpractices. For instance, income tax is evaded through 
non-reporting, under-reporting and misreporting of income. In addition, it could involve maintaining multiple set of account books, fraudulent changes in account books, and keeping transactions out of account books. Income tax can also be evaded through opening and operating bank accounts under assumed names, doing business in the name of dummies, over-reporting expenses, fragmenting income to reduce tax liability, and under-invoicing sales and other transfer pricing manipulations.

Although evasion of tax is a common tendency among people belonging to different groups, opportunities for it vary according to the nature of income earned by taxpayers. In the case of income from salaries and interest from deposits, evasion is less likely because of proper recording and auditing of transactions, and deduction of tax at source. However, opportunities for tax evasion are very large in the case of selfemployed in business and professions. Doctors, lawyers, architects, property dealers, individual contractors can evade taxes more easily than others. They can insist on their customers to pay them in cash or accept invoices which underestimate the payment.

Excise evasion is generally resorted to by adopting, inter alia, malpractices such as incorrect accounting of goods, undervaluation of goods and flouting the conditions subject to which any goods may be exempted from duty.

The proponents of VAT claim that evasion under it is difficult and minimal. The tax credit method ensures cross-checking of the records of taxpayers through invoices. Buyer firms insist on supplier firms to furnish invoices which help the former to claim tax credit. Since tax liability of a single taxpayer under VAT is only a fraction of the total amount of tax, the incentive for evasion is relatively weak. Even a successful evasion would mean less revenue loss as compared to the one suffered under a system of turnover tax on gross value (excise duty or sales tax). Despite the self-policing nature of VAT, opportunities do exist under it for evasion and fraud. In fact, VAT provides opportunities for fraud (fictitious claims for refunds) which are not available under other forms of commodity taxation. The methods commonly applied to defraud tax authorities under VAT include, inter alia, use of fake invoices to claim tax credit, tax credit claims on purchases for personal use, over-reporting of sales of zero-rated goods, secret deals between buyers and sellers as regards issuance of receipts, and formation of fake companies which sell receipts to traders to enable them to claim tax credit on inputs. Thus, VAT is as susceptible to evasion and fraud as any other tax. An efficient tax machinery capable of cross-checking a large number of invoices through an elaborate computer system is a pre-requisite for the successful implementation of VAT.

Evasion of customs duties can take place through invoice misclassification, manipulation of documents and suppression of quantities imported. 


\subsection{Prevention of international tax evasion and avoidance}

\subsection{Arm's length price}

It refers to market price that would have been negotiated by unrelated parties engaged in the same or similar transactions under the same or similar conditions. Arm's length standard is used to prevent the use of transfer pricing technique for tax avoidance. Many countries exercise their right to adjust reported transfer prices to conform to an arm's length criterion. Implementing the arm's length principle is a difficult task for tax authorities.

\subsection{Anti-abuse provisions}

To prevent the misuse of tax treaties through tax treaty shopping, many countries take care to include anti-treaty abuse provisions in these agreements. For example, there is a specific clause in the double tax treaty between India and USA under which benefits of the treaty are available only to genuine residents of either country. In other words, the treaty restricts the use of USA as a treaty shopping centre for investments in India.

\subsection{General Causes of Tax Evasion}

\subsection{High level of tax rates}

Among the host of causes of tax evasion and hence the generation of black money, the level of tax rates is probably the most crucial. It is widely believed that higher the rate of tax, the greater is the tendency to evade taxes. High tax rates make tax evasion more tempting. Tax evaders readily take greater risks if they know that in the event of success the reward is high. Per contra, it can be expected that low tax rates improve tax compliance and broaden the tax base.

\subsection{Less respect for government and its laws}

Tax evasion is more in countries where there is general apathy on the part of people towards the government and its laws. People will have less respect for tax laws if they perceive the tax system to be unfair in terms of level of taxation (tax-GDP ratio) ${ }^{1}$ and/or distribution of tax burden among various classes (i.e. tax equity) ${ }^{2}$. Similarly, there can be a feeling among taxpayers that government is indulging in wasteful expenditure (e.g. digging the roads too often), spending excessively on government functionaries, permitting loan waivers, maintaining perpetually sick public undertakings, and granting unnecessary subsidies. Tax evasion by politicians sends wrong signals to the general public that non-compliance is acceptable. 
It is necessary to change the attitude of the people towards Government and its laws. In this connection, the Indian Tax Reforms Committee, 1991, observed, “...there is a widespread feeling among the electorate that there is considerable waste in government expenditure, that there is excess staff and that the tail to teeth ratio is unduly high. And with it all, it is generally felt that the public which pays the taxes gets poor service and members of the public are treated often not as masters who pay but as supplicants."(Ministry of Finance, 1991, p. 44)

\subsection{Lenient penal action}

Lenient penal action in case violation of law is detected also encourages tax evasion. In general, countries with relatively poor implementation of regulations tend to have a higher share of unaccounted economy, whereas countries with properly implemented regulations and sound deterrence have smaller black economies.

\subsection{Nature of the economy}

The problem of tax evasion in underdeveloped countries is associated with the peculiar characteristics of their economies which, in most cases, are agriculture-based in the sense that a substantial part of national income originates from and the majority of the work force is engaged in agriculture. Moreover, there is widespread illiteracy, lack of accounting practices, limited monetisation and shortage of administrative resources in these countries. A regime of controls, licences, and shortages also breeds tax evasion and black money.

\subsection{Impact of International Tax Evasion on the Economy}

The nexus between tax evasion and black money and its distortion of the redistributive role of tax policy was noted by India's Seventh Five Year Plan (1980-85) as follows, "With a sizeable proportion of income and wealth evading taxation, the redistributive impact of progressive taxation had been severely blunted. A reduction in the scale of black income generation would improve distribution of income and wealth after taxation. Besides, if the magnitude of tax evasion is significantly reduced, there would be a greater volume of tax revenue, and a greater volume of public expenditure benefiting the poorer section of the population would become possible." (Planning Commission, 1985, p. 71)

Black money in social, economic and political space of the country has a debilitating effect on the institutions of governance and conduct of public policy in the country. Governance failure adversely affects the interests of vulnerable and disadvantaged sections 
of society. The success of an inclusive growth strategy ${ }^{3}$ critically depends on the capacity of society to root out the evil of corruption and black money from its very foundations. Undoubtedly, India needs a speedy transition towards a more transparent and result-oriented economic system.

The effects of tax evasion, resulting in black money, on an economy are indeed disastrous. Some of these are listed below:

(i) Tax evasion cuts at the very root of the revenue potential of a tax system and therefore hinders the resource mobilisation efforts of a government. Lack of funds may distort implementation of development plans and force a government to resort to deficit financing in case public expenditure is inelastic.

(ii) Tax evasion may interfere with the declared economic policies of a government by distorting saving/investment patterns and availability of resources for various sectors of the economy. For instance, government may impose credit restrictions to discourage certain activities (e.g. speculation) but money saved through tax evasion may finance and encourage the same activities.

(iii) Evasion of tax seriously undermines the equity attribute of a tax system. Honest taxpayers, who are obliged to bear disproportionate tax burden, feel demoralised and tempted to join the tax evaders' camp.

(iv) Tax evasion leads to the creation of black money which in turn is a menace to the economy in its own way. Tax evasion and black money encourage concentration of economic power in the hands of undesirable groups in the country.

(v) Tax evasion eats into the time and energy of tax administration which is obliged to unravel the intricate manipulations of tax dodgers.

(vi) Tax evasion leads to degradation of social and moral standards. Social abuses like bribery, intimidation, blackmailing, tampering with official records, submitting fake documents etc. all go with tax evasion.

With liberalisation of restrictions on cross-border flow of goods and services and relaxation of foreign exchange control, new opportunities have opened up for tax evasion through tax havens, misuse of transfer pricing, and other sophisticated methods. Globalisation has reduced the cost of these sophisticated methods thereby facilitating generation of black money and its transfer across the border. These changes require new strategies to curb black money.

The fight against generation and accumulation of black money is far more complex and prolonged, requiring stronger intervention of the state. It needs a robust legal framework, commensurate administrative set up, and a very strong resolve to fight the menace. 


\subsection{Various Estimates of Tax Evasion in India}

Widespread tax evasion is a perennial problem of the Indian tax system. The history of taxation law amendments in India is essentially a history of plugging loopholes, as and when discovered, to prevent leakages of revenue.

\subsection{Early attempts}

The problem of tax evasion and generation of black money is not new. As far back as 1936, the Ayers Committee, while reviewing the income tax administration in India suggested large-scale amendments to secure the interests of the honest taxpayer and effectively deal with fraudulent evasion. The Income Tax Investigation Commission was appointed in 1947 to investigate tax evasion and suggest measures for preventing it in future.

Soon after Independence in 1947, the Indian Income Tax Investigation Commission, 1948, investigated all matters relating to taxation of income, with particular reference to preventing evasion and avoidance. The Commission recommended several changes in the law to plug loopholes in the income tax system. It recommended, inter alia, that the law should be amended so as to allow speculative losses to be set off only against speculative gains. Since early 1950s, various commissions, committees and individual scholars have made estimates of tax evasion in India, particularly evasion of income tax. The findings of these studies are summarised below chronologically.

\subsection{Taxation Enquiry Commission (TEC), 1953-54}

The TEC (Chairman: John Matthai), which dealt at length with the administration of income tax, found staggering levels of tax evasion. To quote, "It is observed from statistics in connection with the Disclosure Drive that income as originally included in the returns sent to the income tax department by assessees who made disclosures was grossly understated, the difference between the income as originally returned and that disclosed later to the department being, on the average, as much as 600 percent. Such other statistics as have been made available to us by the Central Board of Revenue also give evidence of the fact that evasion is prevalent on a considerable scale."(Ministry of Finance, 1954, p. 189) The Commission maintained that improvement and strengthening of the enforcement machinery was the only way to tackle evasion effectively.

\subsection{Estimates of Nicholas Kaldor}

Nicholas Kaldor, a British economist, made the first systematic estimates of 
income tax evasion in India in the mid-1950s. He estimated income tax loss through tax evasion at Rs. 200 to Rs. 300 crore for the year 1953-54 (Kaldor, 1956, p. 105). The estimates of Kaldor were based on certain tentative figures relating to national income provided to him by the Central Statistical Organisation (CSO). Kaldor made it clear in his report that his estimates were tentative and should be interpreted with caution. His recommendations resulted in several amendments to the Income Tax Act and new legislations like the Wealth Tax Act.

\subsection{Central Board of Revenue}

Another study by the Central Board of Revenue for the same year (1953-54) recorded a much lower estimate of tax evasion at Rs. 20 to Rs. 30 crore, almost one-tenth of Kaldor's estimate (Ministry of Finance, 1959, p. 148) One main reason for the wide divergence between the two estimates was the inclusion in Kaldor's estimate of what the Central Board of Revenue counted as avoidance rather than evasion. Kaldor himself had admitted while tendering oral evidence before Direct Taxes Administration Enquiry Committee, 1958-59, that his estimate represented the loss of tax not only through evasion but also through avoidance. Therefore, it is generally agreed that the estimates of income tax evasion by Kaldor were on the high side.

\subsection{Direct Taxes Enquiry Committee (DTEC), 1971}

The DTEC (Chairman: Justice K.N. Wanchoo) was appointed in 1971 to examine and suggest legal and administrative measures for unearthing black money and countering evasion and checking avoidance (Ministry of Finance, 1971). It comprehensively dealt with the causes of and methods of tackling tax evasion and made a number of recommendations for strengthening tax administration. It estimated assessable non-salary income for the year 1961-62 at Rs. 2,686 crore and non-salary income actually assessed to tax to be of the order of Rs. 1,875 crore. Accordingly the income which escaped income tax was of the order of Rs. 811 crore. After making rough adjustments for exemptions and deductions, the Wanchoo Committee found that "the estimated income on which tax has been evaded (black income) would probably be Rs. 700 crore and Rs. 1,000 crore for the years 1961-62 and 1965-66 respectively". "Projecting this estimate further to 1968-69 on the basis of percentage increase in national income from 1961-62 to 1968-69, the income on which tax was evaded for 1968-69 was estimated as Rs. 1,800 crore."

\subsection{National Institute of Public Finance and Policy (NIPFP)}

In its study conducted in 1985, NIPFP defined black money as the aggregate of 
incomes which were taxable but which were not reported to tax authorities. The study made use of a range rather than a single figure of underestimation. While preparing the estimate of black income, the study excluded incomes generated through illegal activities like smuggling, black market transactions, and acceptance of bribes and kickbacks. NIPFP study estimated the ratio of tax-evaded income to GDP in the range of 3.7 percent to 5.7 percent in 1975-76, and 4.2 percent to 8.6 percent in 1980-81. (Ministry of Finance, 1985, p.161)

\subsection{Tax Reforms Committee (TRC), 1991}

According to TRC (Chairman: Raja Chelliah), "not more than 30-35 percent of legally taxable income is being disclosed, on the average." (Ministry of Finance, 1991, p. 47) In this context it observed, "it would be fair to say that the income tax department which is in-charge of all the Central Government direct taxes is in shambles. It cannot complain of lack of manpower, but the majority of personnel is constituted by inspectors and clerks who are not adequately trained and are paid fairly low salaries." (Ministry of Finance, 1991, p. 37)

Apart from the foregoing estimates, some evidence of general nature also suggests widespread non-reporting and under-reporting of taxable income in India. In this connection, the Finance Minister in his 1997-98 budget speech observed, "It is inexplicable that in a country of over 900 million people, only 12 million people are assessed to income tax and what is worse, only about 12,000 assessees are in the tax bracket of income above Rs. 10 lakh.” (Ministry of Finance, 1997-98, p. 25)

Estimation of evasion of indirect taxes in India has always remained a hard task even for the officially appointed committees. For example, the Central Excise (SelfRemoval Procedure) Review Committee, 1973, made extensive studies of excise evasion, both sector-wise and commodity-wise. However, it could not quantify the total magnitude of evasion. It observed, "we have reached the conclusion that evasion is considerable and, in certain sectors, pervasive. This is an inference we have drawn from the totality of what we have seen, heard and investigated." (Ministry of Finance, 1973, p. $65)$

\subsection{Agencies for Enforcement of Tax Laws}

\subsection{Central Board of Direct Taxes (CBDT)}

The CBDT, New Delhi, is part of the Department of Revenue in the Ministry of Finance. While the CBDT provides essential inputs for policy and planning of direct taxes in India, it is also responsible for administration of direct tax laws through its 
Income Tax Department. The CBDT is a statutory authority functioning under the Central Board of Revenue Act 1963. The officials of the Board in their ex-officio capacity also function as a Division of the Ministry dealing with matters relating to the levy and collection of direct taxes.

The Income Tax Department is primarily responsible for combating the menace of black money. For this purpose, it uses the tools of scrutiny assessment as well as information-based investigations for detecting tax evasion and penalising the same as per provisions of the Income Tax Act, 1961 with the objective of creating deterrence against tax evasion. In doing so, it plays one of the most important roles in preventing generation, accumulation, and consumption of unaccounted black money.

The Investigation Wing of the Income Tax Department deals with investigations to detect tax evasion and carries out operations like surveys and searches to collect evidence of such evasion. Such operations are usually carried out after detailed preliminary investigations and in cases involving substantial evasion of taxes.

\subsubsection{Directorate of Criminal Investigation (DCI)}

Till recently, the tax administration in India did not have a separate set-up for targeted investigation into criminal cases. On May 30, 2011, a notification was issued by the Government of India for creation of a Directorate of Income Tax (Criminal Investigation) or DCI in the Central Board of Direct Taxes, Department of Revenue, Ministry of Finance. The DCI is mandated to perform functions in respect of criminal matters having any financial implication punishable as an offence under any direct taxes law. The DCI, in discharge of its responsibilities under the direct tax laws, is required to perform the following functions:

(i) Seek and collect information about persons and transactions suspected to be involved in criminal activities having cross-border, inter-state, or international ramifications that pose a threat to national security and are punishable under the direct tax laws.

(ii) Investigate the sources and uses of funds involved in such criminal activities.

(iii) Cause issuance of show cause notices for offences committed under any direct tax law.

(iv) File prosecution complaints in the competent court under any direct tax law relating to a criminal activity.

(v) Hire the services of special prosecutors and other experts for pursuing a prosecution complaint filed in any court of competent jurisdiction.

(vi) Execute appropriate witness protection programmes for effective prosecution of criminal offences under the direct tax laws, i.e. to protect and rehabilitate witnesses who support the state in prosecution of such offences so as to insulate them from any harm to 
their person.

(vii) Coordinate with and extend necessary expert, technical, and logistical support to any other intelligence or law enforcement agency in India investigating crimes having cross-border, inter-state or international ramifications that pose a threat to national security.

(viii) Enter into agreements for sharing of information and other cooperation with any central or state agency in India.

(ix) Enter into agreements for sharing of information and other cooperation with such agencies of foreign states as may be permissible under any international agreement or treaty.

(x) Any other matter relating to the above.

The DCI is headed by a Director General of Income Tax (Criminal Investigation) and functions under administrative control of the CBDT. The head office of the DCI is located at New Delhi and it has eight regional offices all over India.

\subsubsection{Exchange of Information (EoI) Cell}

The Government of India has set up an EoI Cell in CBDT. The EoI works on the basis of mutual cooperation. The competent authorities of different countries provide different forms of administrative assistance to each other based on the provisions of Double Tax Avoidance Agreements (DTAAs) or the Multilateral Convention for Mutual Administrative Assistance. Administrative assistance under these instruments of EOI, depending on the terms of the agreement, may take the form of (a) specific exchange of information, (b) spontaneous exchange of information, (c) automatic exchange of information, (d) tax examination abroad, (e) simultaneous exchange of information, (f) service of documents, and $(\mathrm{g})$ assistance in collection of tax.

\subsubsection{Income Tax Overseas Units (ITOUs)}

With increased scope for international cooperation in areas of exchange of information, transfer pricing, and taxation of cross-border transactions, Government of India decided to create a network of ITOUs. In addition to the existing two ITOUs at Singapore and Mauritius, eight more have been opened. The objectives of these ITOUs are as under:

- Monitor DTAA-related issues.

- Assist the authorities in handling issues arising out of international taxation and transfer pricing.

- Assist the authorities in frequent revision of existing DTAAs. 
- Assist the authorities in negotiation of TIEAs.

- Expedite the exchange of information by the competent authorities (as per DTAAs and TIEAs) of these countries as required by the competent authority in India.

- Assist the authorities in collection of taxes.

- Assist the authorities in work relating to Mutual Agreement Procedure under DTAAs.

- Maintain liaison with various departments of the respective countries especially Income Tax Department, Registrar of Companies, Department of Banking Services, and Administrators of Financial Services.

- Maintain liaison with investors investing in India from these countries.

- Impart information about domestic laws of India to foreign investors.

- Maintain liaison with Indian investors in these countries to assess any tax-related problems arising for these investors.

- Assist the Mission in any other commercial/economic work assigned to the officer by the Head of the Mission.

- Any other work assigned to the officer by the CBDT, Department of Revenue.

Opening of the new ITOUs and presence of tax officers in the ITOUs also acts as effective deterrence against tax evasion.

\subsection{Central Board of Excise and Customs (CBEC)}

The CBEC is a part of the Department of Revenue under the Ministry of Finance, Government of India. It deals with the tasks of formulation of policy concerning levy and collection of customs and central excise duties, prevention of smuggling, and administration of matters relating to customs, central excise and narcotics to the extent under the CBEC's purview. The Board is the administrative authority for its subordinate organizations, including Custom Houses, Central Excise Commissionerates, and the Central Revenues Control Laboratory.

The Directorate General of Central Excise Intelligence (DGCEI) is the apex intelligence organization functioning under the CBEC. It is entrusted with the responsibility of detecting cases of evasion of central excise and service tax. The Directorate develops intelligence, especially in new areas of tax evasion through its intelligence network across the country and disseminates information in this respect by issuing Modus Operandi Circulars and Alert Circulars to apprise field formations of the latest trends in duty evasion. Wherever found necessary, DGCEI on its own, or in coordination with field formations, organises operations to unearth evasion of central excise duty and service tax. 


\subsection{Regulatory Authorities for Supervision and Policing}

\subsection{Central Bureau of Investigation (CBI)}

CBI, functioning under the Department of Personnel, Ministry of Personnel, Pension and Public Grievances, Government of India, is the premier investigating police agency in India. It handles a broad category of criminal cases including cases of corruption and fraud committed by public servants, economic crimes, and other specific crimes involving terrorism, bomb blasts, sensational homicides, kidnappings and the underworld. The CBI plays an important role in international cooperation relating to mutual legal assistance and extradition matters. The Ministry of Home Affairs is the central authority for mutual legal assistance in criminal matters and the Ministry of External Affairs the nodal agency for extradition matters.

\subsection{Financial Intelligence Unit (FIU)}

The FIU-IND was established by the Government of India on November 18, 2004 for coordinating and strengthening efforts for national and international intelligence by investigation and enforcement agencies in combating money laundering and terrorist financing. FIU-IND is the national agency responsible for receiving, processing, analysing, and disseminating information relating to suspect financial transactions. It is an independent body reporting to the Economic Intelligence Council headed by the Finance Minister. For administrative purposes, the FIU-IND is under the control of the Department of Revenue, Ministry of Finance.

\subsection{Narcotics Control Bureau (NCB)}

It functions under the Ministry of Home Affairs, Government of India. It was established on March 17, 1986 and its functions include co-ordination of actions by various offices, state governments, and other authorities under the Narcotics Drugs and Psychotropic Substances (NDPS) Act 1985, Customs Act, Drugs and Cosmetics Act, and any other law for the time being in force in connection with the enforcement provisions of the NDPS Act. It is assigned the task of counter measures against illicit drugs traffic under the various international conventions and protocols, and also assists concerned authorities in foreign countries and concerned international organisations dealing with prevention and suppression of this traffic.

\subsection{Co-ordinating Agencies}

\subsection{Central Economic Intelligence Bureau (CEIB)}

The CEIB functioning under the Ministry of Finance is responsible for coordination, 
intelligence sharing, and investigations at national as well as regional levels amongst various law enforcement agencies. The existing coordination mechanism in the CEIB consists of Regional Economic Intelligence Councils (REICs) at regional level and the Group on Economic Intelligence and meetings of the heads of investigating agencies under the Department of Revenue at the centre. While the Group on Economic Intelligence is focused on matters relating to intelligence sharing, the REICs and heads of agencies meetings cover both intelligence and investigations.

\subsection{National Investigation Agency (NIA)}

It is a specialised and dedicated investigating agency set up under the National Investigation Agency Act to investigate and prosecute scheduled offences, in particular offences under the Unlawful Activities (Prevention) Act, including Financing of Terrorism. The NIA has concurrent jurisdiction with the individual states, thereby empowering the Central Government to probe terror attacks in any part of the country. Officers of the NIA have all powers, privileges, and liabilities which police officers have in connection with investigation of an offence.

The Central Government has the power to suo moto assign a case to the NIA for investigation. The NIA Act also provides for setting up of special courts and trials to be held on a day-to-day basis. The NIA Act can investigate offences under the specific Acts mentioned in the Schedule to NIA Act, including the Atomic Energy Act 1962, Unlawful Activities (Prevention) Act 1967, Anti-Hijacking Act 1982, Suppression of Unlawful Acts against Safety of Civil Aviation Act 1982, SAARC Convention (Suppression of Terrorism) Act 1993, Suppression of Unlawful Acts against Safety of Maritime Navigation and Fixed Platforms on Continental Shelf Act 2002, Weapons of Mass Destruction and Their Delivery Systems (Prohibition of Unlawful Activities) Act 2005, and offences under Chapter VI and Sections 489-A to 489-E of the Indian Penal Code.

\subsection{Other Agencies}

\subsection{Central Bureau of Narcotics (CBN)}

It supervises the cultivation of opium poppy in India and issues necessary licences for manufacture, export and import of narcotics drugs and psychotropic substances. It monitors India's implementation of the United Nations Drug Control Conventions and also interacts with the International Narcotics Control Board (INCB) in Vienna and the competent authorities of other countries to verify the genuineness of a transaction prior to authorising shipments. 


\subsection{Serious Frauds Investigation Office (SFIO)}

It functions under the Ministry of Corporate Affairs and takes up for investigation complex cases having inter-departmental and multidisciplinary ramifications and substantial involvement of public interest, either in terms of monetary misappropriation or in terms of persons affected. It also takes up cases where investigation has the potential of contributing towards a clear improvement in systems, laws, or procedures.

\subsection{Registrar of Companies (ROCs)}

It is the Registry for companies and limited liability firms and is established under the Ministry of Corporate Affairs. The Ministry of Corporate Affairs has a threetier organisational set-up consisting of a Secretariat in New Delhi, Regional Directorates in Mumbai, Kolkata, Chennai and Noida, and field offices in all states and union territories.

\subsection{Registrar of Societies (ROSs)}

The Registrars of non-profit societies are within State Government's purview and most of the states have an ROS office. The Society Registration Act is a Central Act but many states have adopted it with some state amendments and are registering nonprofit societies under their respective Acts. Some state assemblies have enacted completely separate legislation on the subject. The ROS offices are reservoirs of data on societies and also function as their regulator.

\subsection{Economic Intelligence Council (EIC)}

It came into existence in 2003 and is chaired by the Finance Minister and comprises senior functionaries of various ministries and intelligence agencies, including the Governor of the Reserve Bank of India (RBI) and the Chairman of Securities and Exchange Board of India (SEBI). The EIC meets at least once a year to discuss and take decisions regarding trends in economic offences and strategies on intelligence sharing, coordination etc. The implementation of decisions taken by the EIC is monitored by the Working Group on Intelligence Apparatus, set up for this purpose within the EIC.

\subsection{National Crime Records Bureau (NCRB)}

It was set up with the objective of empowering the Indian police services with information technology and criminal intelligence with a view to enabling them to effectively and efficiently enforce the law. It therefore creates and maintains a secured national database on crimes, criminals, property, and organised criminal gangs for use by 
law enforcement agencies. The NCRB also processes and disseminates fingerprint records of criminals, including foreign criminals, to establish their identity.

\subsection{State Police Agencies}

Under the Constitution of India, police and public order are state (provincial) subjects. Every State/Union Territory has its own police force, which performs not only normal policing duties but also has specialised units to combat economic offences. The Economic Offences Wing (EOW) of the police functioning under the administrative control of states (provinces) is entrusted with the responsibility of investigation of serious economic offences and offences having inter-state ramifications.

\subsection{Conclusion}

International tax evasion and avoidance cuts at the revenue potential of the tax system of a country. India also faces the harmful effects of rampant international tax evasion and avoidance through devices such as transfer pricing, tax havens and tax treaty shopping. Various estimates of tax evasion by different committees show that widespread tax evasion has been a perennial problem of the Indian tax system. The history of taxation law amendments in India is essentially a history of plugging loopholes, as and when discovered, to prevent leakages of revenue. India needs tougher laws and stricter enforcement of existing provisions to deal with the root causes of international tax evasion and avoidance.

\section{Endnotes}

1. Level of taxation in a country is traditionally judged in terms of the ratio which taxes bear to some measure of national income. This ratio is called tax-GDP ratio and the change in it is determined by variations in both the numerator (total tax revenue) and the denominator (national income).

2. Tax equity refers to fair or just or equitable distribution of tax burden among taxpayers. Though fairness and justness in taxation are universally accepted, these terms are rarely defined rigorously and can be interpreted in various ways. Hence, there is no unanimity of opinion as to the type of tax system which results in the most equitable distribution of tax burden.

3. Inclusive growth may be defined as growth that promotes equal opportunities and increases access to these opportunities, i.e. growth that allows all members of society to participate in and contribute equally to development efforts, regardless of individual circumstances. This concept appears in Asian Development Bank's (ADB) Strategy 2020 that examines the extent of inequality of opportunities and to what extent it can be overcome by different types of growth 
process. The main idea in the ADB's approach is to focus on productive employment as an important element of inclusive growth. Inclusive growth, defined in a broader sense has three dimensions: (a) Equity among all sections of the society. (b) Equity among all sectors of the economy. (c) Equity among all regions in the country. Thus, inclusive growth means inter-group, inter-sector as well as inter-regional equity. Growth is inclusive when it creates economic opportunities along with ensuring equal access to them.

4. Derivative instruments are defined by the Indian Securities Contracts (Regulation) Act, 1956 to include (a) a security derived from a debt instrument, share, secured/unsecured loan, risk instrument or contract for differences, or any other form of security and (b) a contract that derives its value from the prices/index of prices of underlying securities. In other words, derivatives are financial instruments/contracts whose value depends upon the value of an underlying. Since their value is essentially derived out of an underlying, they are financial abstractions whose value is derived mathematically from the changes in the value of the underlying.

\section{References}

Kaldor, N. (1956). Indian Tax Reform: Report of a Survey (Government of India, Ministry of Finance, 1956).

Ministry of Finance, Government of India (1985). Aspects of the Black Economy in India, March.

Ministry of Finance, Government of India. (1954). Report of the Taxation Enquiry Commission (Chairman, John Matthai), 1953-54, Volume II.

Ministry of Finance, Government of India. (1959). Report of the Direct Taxes Administration Enquiry Committee (Chairman: Mahavir Tyagi), 1958-59.

Ministry of Finance, Government of India. (1971). Final Report of Direct Taxes Enquiry Committee (Chairman, Justice K.N. Wanchoo), December.

Ministry of Finance, Government of India. (1973). Report of the Central Excise (SelfRemoval Procedure) Review Committee (Chairman: B. Venkatappiah).

Ministry of Finance, Government of India. (1991) Interim Report of the Tax Reforms Committee (Chairman, Raja Chelliah), December 1991.

Ministry of Finance, Government of India. (1997-98). Budget 1997-98, Speech of the Finance Minister, Part B. 
International Tax Avoidance and Evasion with Special Reference to India | 39

Ministry of Finance. Government of India. (1991). Interim Report of the Tax Reforms Committee (Chairman: Raja Chelliah), December.

Planning Commission, Government of India. (1985). The Seventh Five Year Plan (198590), Volume I. 